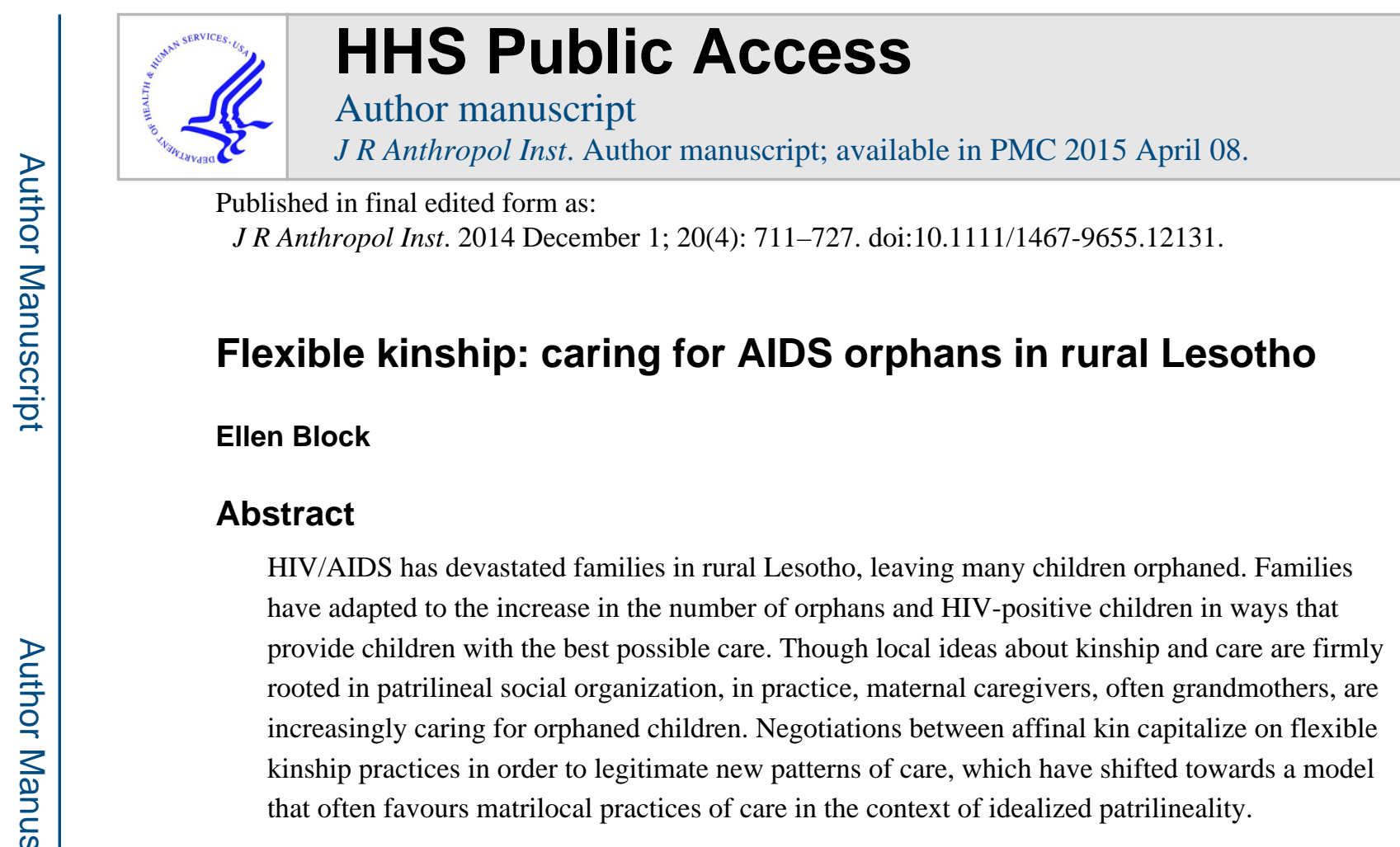

\title{
Kinship in practice
}

When 'M'e ${ }^{1}$ Lehela was six months pregnant, she became sick with AIDS. Her husband was working in South Africa, and her mother-in-law was not providing her with the care she needed, so she moved with her two children to stay with her mother, 'M'e Matau, in the rural highlands of Lesotho. In late 2005, 'M'e Lehela died of AIDS shortly after her son, Thato, was born, leaving three children behind with her mother; a common pattern of illness-related migration in contemporary Lesotho and elsewhere (Adato, Kadiyala, Roopnaraine, Biermayr-Jenzano \& Norman 2005; Urassa et al. 2001). At the time of his mother's death, Thato had a CD4 of 16 per cent, well below the threshold for beginning antiretroviral treatment (ART). ${ }^{2}$

In addition to caring for Thato's mother and her children, 'M'e Matau also cared for the orphaned child of another daughter with the help of her son and daughter-in-law, who lived next door. I asked 'M'e Matau about Thato's paternal grandparents, since the patrilineal social organization to which Basotho ascribe dictates that children of a married couple belong to the father's family (Ashton 1967; Murray 1981). She said that after her daughter died, the paternal grandparents sent a letter asking for the children. However, she feared they would not take good care of them, since they had failed to do so before her daughter's death. She also disagreed with her daughter's in-laws about the identity of the children, who belonged to her clan and shared her last name. She said, 'No, I didn't agree with them because these are my children (bana ba ka) ... I said, you didn't pay likhomo [bridewealth, or, literally, cows]'. 'M'e Matau, like many Basotho, uses ideals of patrilineality to negotiate for the care of maternal orphans.

1'M'e is Sesotho for 'Mrs' or 'mother'. Ntate is Sesotho for 'Mr' or 'father'. All names are pseudonyms.

${ }^{2} \mathrm{CD} 4$ is a measurement of immunodeficiency used to approximate the viral load of a person living with HIV/AIDS. Children's CD4 is measured in percentages. Severe immunodeficiency ranges from 15 percent or less to 30 per cent or less, depending on the child's age. 
Kin-based networks, though strained by AIDS, are still the primary mechanisms for orphan care in Southern Africa (Adato et al. 2005; Prazak 2012; Zagheni 2011).However, in-depth explorations of caregiver experiences are limited and we have yet to understand how extended kin have remained afloat in light of this caregiving challenge (Cooper 2012; Kuo \& Operario 2009). This research, which took place in the rural, mountainous district of Mokhotlong, Lesotho, provides a detailed examination of the daily struggles, negotiations, and concerns of caregivers in one of the many remote and vulnerable communities impacted by the AIDS pandemic. ${ }^{3}$ I present in-depth ethnographic evidence to illuminate exactly how families are reorganizing themselves in order to maintain kin-based care in this context.

I show how a novel way of negotiating for the care of orphans has emerged that no longer privileges patrilocality. While other regional studies have also noted a move away from ideals of patrilineality in fostering patterns (Adato et al. 2005; Howard et al. 2006; Oleke, Blystad \& Rekdal 2005), this article looks at how deeply embedded patrilineal ideals persist despite practices that seemingly subvert them. Among Basotho families, there has been a gradual shift towards increasing care by maternal relatives, the majority of whom are grandmothers. Paradoxically, the process of negotiation and justification that occurs when families are deciding on the locality of care for orphans highlights the continued adherence to the principles of patrilineal descent, while in practice, care has emerged as the strongest motivation for new patterns of social organization. Kinship continues to be intrinsic to the very notion of care; as a result, few orphans are cared for outside of the family. Increasingly, it is the willingness to care, or what Borneman calls 'processes of voluntary affiliation' (1997: 574), as demonstrated by everyday acts of caring, that have become most important in influencing patterns of child circulation. This, in turn, impacts the very nature of relationships between kin (Klaits 2010).

At the family level, there has been considerable flexibility in caregiving patterns. At the structural level, there has been an increase in matrilocal care that remains to be understood as part of a patrilineal system of fostering. The gap that exists between Basotho's kinship ideology and their caring practices can be explained, in part, by the differentiation Bourdieu makes between 'official' and 'practical' kin. Whereas 'official kin' is the representation of kinship for the public sphere by the group as a whole, 'practical kin' is 'directed towards the satisfaction of the practical interests of an individual or group of individuals' (Bourdieu 1977: 35). People actively forge relationships based on their practical needs, in spite of the tenets of 'official kin' doctrine. While Basotho may frame their negotiations as structured by an inflexible set of rules, in reality they are working within a series of competing ideologies, or, as Comaroff puts it, a 'repertoire of potential manipulations' (1978: 4). Far from being a simple dichotomy between stated norms and practices, relatedness is processual in nature, allowing caregivers to navigate an array of seemingly conflicting possibilities structured by patrilineal ideals, which are inevitably constrained by the political-economic and social context of which they are a part. Caregivers work within these constraints, often emphasizing idealized rigidity rather than flexibility, in order to make the desired forms of

${ }^{3}$ Lesotho has a 23.6 per cent HIV-prevalence rate, the second highest globally (UNAIDS 2012). 
relatedness appear more or less novel, traditional, or incompatible, depending on their intended outcomes.

This article will explore how and why a decline in customary patrilineal practices has not been matched by their lessened importance. As many of the following case studies show, bridewealth payment is particularly potent in caregiving negotiations because it is 'the idiom for gender relations in which everyone is fluent' (Wardlow 2006: 133). In an African context, it is also a system with enough flexibility and opportunity for manipulation that it serves the negotiator in navigating the idealized patrilineal landscape. While bridewealth may emerge as the most frequently used negotiation tool, the underlying principle driving the negotiations is care. It is within a context of embedded child fostering, changes in marriage, a decline in bridewealth practices, and high rates of migrant labour and disease that a shift towards matrilocal care must be viewed.

Contemporary approaches to the diverse field of kinship emphasize the various and dynamic ways of constructing and understanding relatedness in order to illuminate processes of social change. As many kinship theorists have demonstrated, relatedness is not fixed but is processual and exists in a particular historical, socio-economic, and geopolitical context (Carsten 2000; Franklin \& McKinnon 2001). As Bloch and Sperber (2002) note, while a complete shift between matrilineal and patrilineal systems is rare, dispositions towards certain relatives are locally and historically specific and change over time. In Lesotho, kin relations have changed because of a number of historical and political-economic pressures, including AIDS.

This work is based on sixteen months of ethnographic fieldwork in the rural highland community of Mokhotlong, Lesotho, between 2007 and 2013. I employed a multifaceted ethnographic approach which included surveys, in-depth semi-structured interviews, participant observation, archival work, and textual analysis. I primarily explore the care of young children (birth to 5 years old) because they require labour intensive daily care that highlights the challenges of this work without the immediate potential for household assistance that an older child might provide. Because of the young age of the children, there was little difference in gender preference by caregivers.

The majority of caregivers in this study were caring for children who had at some point received services from a local NGO, Mokhotlong Children's Services (MCS). MCS clients are typical of families fostering orphans in that they suffer from poverty, food insecurity, drought, and are impacted by the ravages of AIDS. Like the general rural population, MCS clients also range in their vulnerabilities. The majority of orphaned clients are situated with a caregiver before receiving services from MCS, so caregiving trends described here were not impacted by caregivers' service participation. Although my initial contact with caregivers was facilitated by MCS, long-term engagement, my ability to measure caregiver selfreporting against observations, and my own reflexivity about potential biases helped to minimize the pitfalls associated with the nature of my relationships with caregivers.

In this article, I contextualize patterns of children's migration in contemporary Lesotho with an overview of child fostering practices and the ways they have been impacted by AIDS, 
migrant labour, and changes in the institution of marriage. I then explore ideologies of care and caregiving practices, acknowledging a shift away from patrilineal patterns of social organization. Finally, I demonstrate the ways in which negotiations for the care of AIDS orphans utilizes the cultural logics of bridewealth and patrilineality in order to justify a range of configurations of care.

\section{Situating caregiving: fostering, migrant labour, and marriage}

Like many of the grandmothers I spoke with, 'M'e Matau lived with her own maternal grandmother from early childhood until she was 15 years old. She was sent by her parents to provide companionship and to assist her grandmother with household chores. Basotho like 'M'e Matau use what they know about fostering from their own experiences and adapt it to accommodate shifting domestic arrangements stemming from the increase in the number of orphans. While this recent increase is perhaps more dramatic owing to the severity and scale of the AIDS pandemic, caregiving practices, including child fostering, have always been in flux, shifting in response to historical and political-economic circumstances. In this section, I situate long-standing child fostering practices that serve as the basis for the contemporary movement of AIDS orphans, and trace the legal and historical processes that have impacted these practices, with a focus on migrant labour and marriage.

Child fostering has been widely studied across the African continent (Bledsoe 1989; Goody 1982; Madhavan 2004; Renne 1993). It is typically characterized by the movement of children for a variety of purposes related to health, fertility, social responsibility, caregiving relationships, apprenticeship, and educational opportunities. Despite numerous characterizations of fostering as fundamentally reciprocal in nature (Bledsoe 1989), such practices are not always beneficial or voluntary. Several scholars have highlighted the role that poverty plays in the circulation of children, often transferring the productive contributions of children from one household to another (Goody 1982; Leinaweaver 2007; Schrauwers 1999). Thus, processes that shape social relationships are not always unambiguously positive, alliance-building strategies, but may also be necessitated by poverty, inequality, and disease.

Child fostering has a long history in Lesotho as a regular strategy for sharing responsibility and supporting and connecting kin (Murray 1981; Page 1989). In Lesotho, HIV/AIDS has been a major factor in changing fostering patterns, as it has elsewhere in sub-Saharan Africa. ${ }^{4}$ Household migration has been an important coping strategy employed by children and families impacted by AIDS (Ansell \& van Blerk 2004). Although orphans are still predominantly cared for within the family, researchers worry that family and communitybased networks of care are becoming saturated (Abebe \& Aase 2007; Courtney\&Iwaniec 2009; L. Townsend \& Dawes 2004). Others also note that increased pressure on caregivers has resulted in some children receiving inadequate care, as caregivers struggle to meet these children's needs, whether financial (Ansell \& van Blerk 2004; Kidman, Petrow \& Heymann 2007) or emotional and psycho-social (Ansell\&Young 2004; Nyesigomwe 2005). The emergence and uncertainty of matrilocal care must be understood as embedded in a context

\footnotetext{
${ }^{4}$ UNICEF (2010) estimates that there are 110,000-120,000 AIDS orphans in Lesotho; of these children, 12,000 are HIV-positive.
} 
that is constrained not only by AIDS and poverty but also by a variety of historical and contemporary factors, including legal and political economic shifts spanning over a century.

Customary law in Lesotho is based on the Laws of Lerotholi, which were codified in 1903 under the direction of British colonial administrators (Juma 2011). According to these laws, the rights of children are legitimated by the valid marriage of their mothers and hinge on bridewealth payments (Poulter 1977). Recent legal advances, including amendments to the Land Act of 1979 (Larsson 1996) and the Legal Capacity of Married Persons Act of 2006 (Mapetla 2009), have removed the minority status of women and protected their rights to property and custody of their children. In theory, customary law can no longer be upheld by civil courts; however, in practice it is still frequently relied upon in resolving legal disputes. ${ }^{5}$ Lesotho's National Policy on Orphans and Vulnerable Children (Department of Social Welfare 2006) does not articulate specific protection for caregivers, but merely asserts a need to support kin-based care more generally. Maternal caregivers experience insecurity because their position as caregivers is unstable. Far from being overshadowed by emerging logics of care, patrilineality is still dominant, despite its ambiguous legal status.

Key aspects of Basotho social life have also been impacted by a myriad of factors, including South African apartheid, deteriorating soil quality, an increased reliance on cash income, a growing trend towards urbanization, and, most importantly, migrant labour. Lesotho's position as a remittance economy greatly impacted Basotho at the family level. From the 1860s, Lesotho was dependent on migrant labour to South Africa, primarily for mine work (Kimble 1982; Murray 1977). At its peak in the late 1970s, Lesotho's 'perpetual state of economic dependency' (Romero-Daza \& Himmelgreen 1998: 200) on South Africa greatly disrupted both the jural and conjugal stability of marriage, which would later help to fuel the spread of HIV/AIDS (Marks 2002;Murray 1980). Apartheid laws prohibited women from joining their husbands in the mining camps, and 'the enforced separation of spouses generate[d] acute anxiety, insecurity and conflict' (Murray 1981: 103).

Once HIV/AIDS began to spread in South Africa, Basotho families experienced the unforeseen health consequences of the remittance economy. Migrant labourers were among the most vulnerable populations, contracting HIV from sex workers or longterm partners in South Africa and spreading the virus to their spouses while on home visits (Romero-Daza \& Himmelgreen 1998). Though migrant labour to South Africa is no longer as pervasive in Lesotho because of widespread mine closures (Spiegel 1981), subsequent trends in increased female labour migration and rural-to-urban migration for a fluctuating textile industry (Coplan 2001; Crush 2010; Gay 1980; Turkon, Himmelgreen, Romero-Daza \& Noble 2009) continue to disrupt social life and to increase Basotho's risk of exposure to HIV. While the majority of Basotho no longer benefit as widely from the economic advantages of migrant labour, they are still adversely affected by its social and health consequences.

This entrenched remittance economy and its coincidence with apartheid and HIV/ AIDS have had far-reaching impacts on other facets of economic and social life in Lesotho that have been well documented, such as changing cultural identities among migrants (Coplan

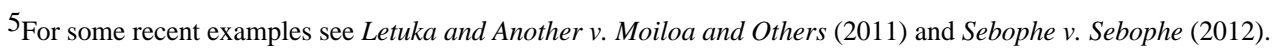


1991), shifting property structures (Ferguson 1985; Turkon 2003), the development of class antagonisms (Spiegel 1981; Turkon 2009), and fluid gender roles (Epprecht 1993; Gay 1980; Gordon 1981). The institution of bridewealth in particular has been greatly impacted by these multitudinous factors, and as a result has been fundamental in changing marriage, gender relations, and caregiving practices (Ferguson 1985; Murray 1980; Turkon 2003). AIDS care must be viewed as situated firmly within this changed and changing landscape.

Changes in African marriage are difficult to measure quantitatively because of its processual nature and because of the many different forms of socially recognized marriage that are available (customary, religious, and state) (Meekers 1992; N.W. Townsend 1997). Despite the absence of precise data, there is nevertheless a consensus that marriage in sub-Saharan Africa has been marked by increased dissolution (Mokomane 2013) and the decreased value of formal unions (Meekers \& Calves 1997). In Lesotho, until recently, bridewealth was extremely common and marriage strategies gave women access to remittances (Boehm 2006; Gay 1980; Mueller 1977).However, the retrenchment of male migrant labour and the increasing feminization of the labour market means that women often do not need marriage as a strategy to access remittances, and men's ability to fulfil their role as provider has diminished (Boehm 2006; Hosegood, McGrath \& Moultrie 2009). Childbearing remains important to achieve full social recognition, even in the context of high HIV rates (Booth 2004; Smith 2004). While marriage is still the primary site of reproduction (Dodoo 1998), and can be seen as a way to formalize the protection for a mother and her children (Boehm 2006), it becomes less motivating in the context of increased female access to wage labour and the deterioration of relations with affinal kin on whom a woman (and her children) would customarily rely for care and protection within the bounds of a socially recognized marriage.

I return here to the idea of competing ideologies as it is useful in thinking about changes in marriage and their inevitable impact on the movement of children in the contemporary Basotho context. As Bourdieu proposes, marriage strategies are meant to seek not just any partner but a 'good' partner, and need to be seen as 'one element in the entire system of biological, cultural and social reproduction' (1976: 141). The constraints around marriage are numerous, and modern pressures can clash with more traditional cultural logics to create uncertain and varied understandings of the economic and social benefits of marriage for both adults and children. These competing ideologies (and realities) that surround contemporary marriage in Lesotho call into question whether marriage is, indeed, a 'good' strategy for women and children.

\section{Privileging care}

In order to understand patterns of orphan care, it is important to establish what care means in the context of AIDS. There are three basic means of contributing to orphan care that pervade the social landscape: material assistance, routinized care that oversees established regimens (such as monitoring ART adherence), and intensive daily physical care, often in response to emergencies such as parental death. In this article, I focus on these daily aspects of caregiving because of the role they play in shaping relatedness. While caregivers include grandfathers, aunts, uncles, and siblings, the majority of caregivers presented here are 
grandmothers. As the last virtually HIV-free generation of adults, and because of a preference for female caregivers, grandmothers bear the majority of the care burden (Cook et al. 2003; Robson, Ansell, Huber, Gould \& van Blerk 2006). However, this trend in caregiving is also explained by the strong intergenerational bonds that have long been the subject of anthropological inquiry (Levi-Strauss 1969; Radcliffe-Brown \& Forde 1950). A good caregiver was often described to me as 'having love' (kena le lerato). Or, as one greatgrandmother said of her son, who was caring for his two young grandsons: 'I can see that it's his heart' (Ke ea bona hore e ka pelong ea hae). In contrast, I heard dozens of times that Lesotho's social ailments were because 'there is no more love' (ha ho sana lerato). Love in Lesotho, as elsewhere in Africa, is often conceptualized and enacted through labour, including the labour of care (Cole 2009; Klaits 2010).

'M'e Maliehi, the maternal grandmother of 2-year-old Matseli, claimed that love and experience made elderly people better fit to care for children.

The young people don't know how to take care (thokomelo) of a family ... Like you small girls, if you are sent somewhere you will just take a long time being there ... The sun will set while you are still there not knowing what the kids will eat. But me, I will be here always.

She claimed that elderly people were more willing to provide care for an orphan because 'The old people have love'. She demonstrated this love repeatedly for her grandson. When 'M'e Maliehi was told that Matseli would be returning from the residential facility at MCS after spending almost a year there, she stood up and danced and sang ' 0 tla fihla, abuti oa ka, o tla fihla' (He is arriving, my boy, he is arriving). Basotho concepts of love are influenced by emotional attachment, and shaped by cultural ideas about loving relationships that include the importance of children, filial responsibility, the social expectation of kin-based care, and demonstrations of love through physical acts of caregiving. Affection in this social context is experienced individually and socially, and helps to protect children orphaned by AIDS.

Stories of good care among Basotho focus on bodily care and material provision in the context of caregiving relationships. Inadequate care is discussed in terms that emphasize dirtiness, lack of food, overly hard work, and preferential treatment for some children over others. Despite a discourse dominated by the material and economic facets of care, I repeatedly witnessed the strong emotional connection between caregivers and children. For example, one Friday I visited 1-year-old Letlo and discovered that his antiretroviral medication was going to run out over the weekend when the clinic was closed. His grandmother,'M'eMapole, had to take him to the clinic that day; however, because I had come by motorcycle, I was not able to give them a ride. Instead of setting off for the twohour trip to town, his grandmother spent an hour heating water over a fire for his bath, even though the child appeared perfectly clean. Scholars such as Livingston (2008) have emphasized the importance of bodily aesthetic practices to sociability and personhood. Bathing is particularly powerful, as Durham notes, because 'the labor involved in preparing a bath enters into negotiations of loving care' (2005: 191). 'M'e Mapole took excellent care of Letlo. She was extremely diligent about keeping him clean, not only for his benefit, but as an outward sign to others that she was an adequate caregiver. 
Most of the caregivers I spoke with, young and old alike, agreed that it is the father's side of the family who is responsible for orphans according to 'Sesotho culture' (meetlo ea Sesotho). Basotho still hold strong ideals about patrilineal inheritance, naming, gender roles, marriage practices, and the lineages of children. However, in response to the increase in AIDS orphans, configurations of care that are not in line with patrilineal rules about residence are occurring across Southern Africa (Adato et al. 2005; Cooper 2012; Howard et al. 2006; Ksoll 2007; Nyambedha, Wandibba \& Aagaard-Hansen 2003; Oleke et al. 2005).While child fostering (or any other cultural practice, for that matter) has never aligned with idealized rules, and while historical data detailing the care of orphans in Lesotho are sparse, there is reason to believe that this pattern of care is occurring with increasing frequency.

In Lesotho, most people are surprisingly flexible when it comes to the locality of care, and agree that it is important to ascertain the best environment for a child on a case-by-case basis. As one young maternal caregiver told me, '[The family is] just looking at the situation, how the children are going to grow up'. This sentiment was expressed by many, including one maternal great-grandmother who said, 'Ache! I don't like the rules. It's better if you can look at the situation for how we should help the children'. Ideally, caregiver quality is assessed not merely by the ability to meet the physical needs of the child, but also according to the character of the caregiver, the proximity of the kin connection, and the ability of a caregiver to provide love to a child (Goldberg \& Short 2012).'M'e Nthabiseng, the managing director of MCS, agreed that care is being privileged over customary norms. She said:

Culturally, a child from a married couple belongs to the father's side. But what I see happening now, children not living with their parents go to either side of the family depending on relationships of both families, who is willing to have an additional child in his or her family and which side has a living grandmother. I am saying this because with the existing poverty, people on both side[s] are hesitant in volunteering to care for children ... [T] hese days it does not really matter which side the children are cared for but what is important is the side that is willing to provide better care.

A child's embeddedness in the paternal family depends on ill-defined and changing markers of patrilineal social organization, such as bridewealth, that are no longer reflected in patterns of child circulation and care.

Over three-quarters of MCS clients between 2007 and 2012 not living with a parent were living with a maternal relative, the majority of them grandmothers. This strong trend towards matrilocal care among orphaned and vulnerable children confirms that care takes primacy over other influences on social organization such as lineality and idealized cultural norms. The most striking aspect of this emerging system of care is the way in which matrilocal care is being negotiated, as potential caregivers use the rules of patrilineal marriage and descent to make claims for children outside of the patrilineage. As contemporary kinship theorists such as Borneman (1997) and Butler (2002) suggest, people adapt and stretch rules in order to privilege care over other, more rigid aspects of kinship such as descent and alliance. 


\section{Negotiating matrilocality}

Deciding on a home for a child is often a complex process of negotiation between family members on both sides. If maternal relatives believe that they are best able to care for a child, they frequently invoke often ignored rules of patrilineality in their negotiations. In numerous cases, women returned with their children to their natal homes during their illnesses. However, the prevalence of maternal caregivers is not merely due to inertia based on the location of the children at the time of their mother's death; the historically frequent circulation of children points to Basotho's ease and comfort with this movement. Instead, it is weakened marital relationships and the consistent importance of care that has led to this recurring pattern. This section demonstrates some of the ways caregivers invoked patrilineal norms in order to negotiate for the care of children within the maternal family.

In many of the examples presented here, the lack of bridewealth payment was the cultural lynchpin on which maternal caregivers based their claims. Even when a couple marry without the intent of paying bridewealth, the strength of the cultural practice and the presence of a generation of older adults for whom it remains important mean that the possibility of bridewealth exists. 'M'e Matau claimed that the children belonged to her since the husband's family 'never sent cows' (o se hiole o romella likhomo), or bridewealth (likhomo). In the current economy it is common for couples to marry without bridewealth, and there are many paternal grandparents who care for their grandchildren regardless of bridewealth payment.However,'M'eMatau wanted to keep the children, so she used the absence of bridewealth to justify her position. She claimed that the paternal grandparents did not really want the children because 'they just talk' (empa ba bua feela). She believed that their motivations were purely economic: 'They just want to eat with them. They just want these children towork for them'. By claiming that the in-laws merely wanted to 'eat with' (ho ja ka) the children, she negatively links the children's labour to their livelihood. Although there was obvious affection between 'M'e Matau and her grandchildren, she also recognized the value in their labour. She said, 'I like them to help me because I have been caring for them'. The mutually beneficial relationship between caregiver and child is one of the many functions of child fostering (Bledsoe 1989), and does not preclude love in caregiving relationships (Goody 1984;Klaits 2010).Yet it is presented as unethical by 'M'e Matau when discussing the paternal grandparents because it helped strengthen her social (as opposed to legal) claims to care for the children.

Ntate Kapo's ability to secure care for 3-year-old Kotsi and his brother also relied on a claim about bridewealth; but again, the lack of care by the paternal kin was this maternal grandfather's primary concern. Kotsi's mother returned home during her illness, and passed away in her father's arms. Kotsi's maternal grandfather, Ntate Kapo, was one of a small but growing group of male primary caregivers I encountered. He repeatedly commented on the motherly nature of his relationship with his grandsons, thus reinforcing the deeply embedded gendered nature of care. Ntate Kapo told me that Kotsi's paternal relatives did not 'follow the rules' (latela litaelo) and did not 'do Sesotho culture properly' (ha a etsa meetlo ea Sesotho ka nepo), thus reinforcing the rules in order to legitimate his own actions. According to Ntate Kapo, Kotsi's mother was not being cared for during her illness, so she returned home to her father. After a few months, the paternal grandparents came to take back the children. 
Ntate Kapo said, '“The children of whom? Because you did not even pay bridewealth". Because they did not even come [to the funeral] when their mother died. And they went back without anything ... They would not take me to the court because they did not pay bridewealth'. Although most Basotho negotiate care without involving the courts, legal redress remains a possibility. Kotsi's paternal grandparents could not make a legitimate legal or social claim for him and his brother because they failed to adhere to customary laws regarding marriage as well as care. Ntate Kapo told me that children may only live with their paternal relatives if bridewealth has been paid, despite the ambiguous role bridewealth currently plays in determining caregiving arrangements. In this way, he positioned himself as a strong enforcer of the rules of patrilocality, and then legitimated his status as caregiver by demonstrating how the paternal family did not follow these rules.

'M'e Malefu's case was similar to Ntate Kapo's in many ways. She cared for her daughter's two school-aged girls. Her daughter had been married, with the expectation that the 'cows would follow' (Iikhomo li tla latela); however, the family was unable to pay, so 'M'e Malefu claimed they were not married. She also said that the in-laws were not caring for her daughter, and like the previous example, they failed to attend her funeral. However, unlike Ntate Kapo, she and her husband went to court to legalize their claim for the children, even though the paternal relatives sent a letter from their chief saying that 'M'e Malefu could have the orphaned girls. I asked her why she took this legal precaution despite the paternal family's apparent lack of interest in the children. She said: 'We went to the court because we wanted things to be certified (pakahatsa). Not to agree only'. It is interesting that she repeatedly mentioned that bridewealth had not been paid - this being her legal claim to the children. Yet she also emphasized a lack of care on the part of the paternal family as her primary motivation for her legal actions. Despite the formal separation of Sesotho and government laws in Lesotho, 'M'e Malefu used both customary and formal legal structures to achieve particular social ends. In this case, the legal claims reinforced the kinship claims, which were fundamentally about quality of care. However, there is the devastating potential that the legal and kinship claims might contradict each other, which creates insecurities for caregivers and children.

The Nthos, an elderly couple in their seventies, were also caring for their maternal grandchildren because their daughter migrated with her children to her natal home during the late stages of her illness. Both the mother and youngest child were HIV-positive. The grandfather, Ntate Bokang, said, 'The parents on the father's side were not taking care of the mother ... They were not taking care at all'. However, these maternal grandparents felt deeply insecure about the lack of formality in their arrangement:

Grandfather: When we die, what is going to happen? Because we don't have a boy. What is going to happen to our houses? I don't know ...

Grandmother: Me,I just think what if Ntate-Moholo [grandfather] and I, we can both die, who is going to take care of these children of my daughter? Because we are the ones taking care of them. Because, on the father's side, they seem not to take care of them. And I'm always praying to God to help me so that I can live for a long time and they should be old enough to do things for themselves. 
Although the paternal family had shown no interest in caring for the children, the Nthos harboured concerns about the children's future. Ntate Bokang said, 'Because we are the parents of their mother we have to take care of them. When they grow up and if they want to go to that family [father's side] they will go because they are still using their surname (fane)'. The unspoken concern was that once the children were old enough to make significant contributions to the household, especially in terms of agricultural work, the paternal family would want them back. The Nthos' substantial caregiving investment was not enough to ensure that the children belonged to them. When the Nthos' daughter married her husband, he paid four cows, an acceptable initial payment at the time of marriage. This partial payment created insecurity for the Ntho family.

The emphasis on bridewealth payments in negotiating caregiver rights is notable because in practice bridewealth is a fading, though not extinct, practice among Basotho. Historically, bridewealth reinforced the processual nature of a union, whereby an initial payment was made at the time of marriage, with the remaining cows (or agreed-upon equivalent of cash, goods, or other animals) paid over time (Ashton 1967; Murray 1981). Contemporary marriage, though less reliant on bridewealth, is still conceived as a process as opposed to an event (Comaroff \& Comaroff 2001; Murray 1976; N.W. Townsend 1997). While many Basotho participate in legal and/or customary marriage ceremonies, others consider cohabitation to signify the start of their marriage. As a result, the marital status of a couple, and consequently the appropriate caregiver for orphans, is less obvious and more open to negotiation.

Elderly Basotho are more likely than young people to extol the value of bridewealth in strengthening a marriage, and conversely to attribute the dissolution of marriages to the decline in bridewealth practices. Indeed, several elderly Basotho told me that when they fought with their spouses, their parents encouraged them to 'be patient' (eba le mamello). As one elderly grandmother said, 'Nowadays, they just get married and no one stands between them. Because there are no likhomo [cows]'. Here, she reinforced the view that bridewealth creates bonds between affinal kin that make divorce more difficult. Young people living in rural areas, or those who self-identified as traditional — or as one father put it, 'sotho-sothosotho' (meaning, very Sesotho) - were more likely to value bridewealth. For example, 42year-old Ntate Kalase, who had promised six 'cows', but only provided two before his inlaws died (which he paid for in cash), said that marriages would be stronger if bridewealth was paid. He believed that 'men would be crying for their cows' (banna ba tla Ilela khomo tsa bona), or working hard to stay in their marriages in order to keep the bridewealth within their families. Yet unlike elderly people who lamented the decline in bridewealth as well as the decrease in its monetary worth, 'M'e Mapole, a young mother, was realistic about the current economic constraints young people faced, while still seeing value in the symbolic exchange:

Paying likhomo [cows] doesn't mean the kraal should be full of them. But, if you have paid for one, it's enough. Even if it wasn't the same as in the past, but it should be paid. Because most of the people can't pay that amount that was paid in the past. There are few people who can pay that now. 
While all of the elderly caregivers had received some bridewealth at the time of their marriages, only a handful of young parents had received any. Several young adults told me that they did not view bridewealth as important, that it was a drain on resources, and that a couple could marry without it. Newly married 'M'e Masenate, aged 19, who was having problems with her husband, told me that divorce was unrelated to bridewealth and that 'if you feel like going you must go', but that 'the old people were always saying you should go back and sit down and solve the problems'. Decline in bridewealth among young people was often explained to me in social terms, yet in reality, very few young married couples have access to the necessary surplus wealth that was previously the result of both labour opportunities and the bridewealth exchanges of close kin. As Turkon (2003) notes in his study of cattle in Lesotho, idealized patterns of bridewealth are seldom practised anymore, and current bridewealth practices utilize a variety of strategies in negotiating this tradition. Of course, idealized practices are rarely followed closely, and marriage patterns do not have to be commonly observed in order to be mobilized to assert kinship claims. Yet, bridewealth payments of any size were previously the norm and are increasingly the exception, retreating even further from the practice in its idealized form.

Despite these changing attitudes and practices around bridewealth, as a cultural ideal it still carries weight when caregivers are negotiating for the rights to foster orphans. Such negotiations are strategically used by caregivers when there is disagreement or insecurity about the relationship of the child to the caregiver or the location of care. In these cases, quality of care, which is closely linked to willingness to provide care, was the deciding factor in finding a home for the children. Care is the primary consideration in determining fostering arrangements, but bridewealth emerges as an important source of cultural and legal capital when there is a dispute or insecurity.

However, not all caregiving arrangements are negotiated based on the presence or absence of bridewealth. For example, two of the grandmothers I interviewed extensively were caring for their daughters' children even though bridewealth had been paid, at least in part. In contrast, another grandmother was caring for her paternal grandchildren even though bridewealth had not been paid. In the current context of marital instability and illness, many young women across Africa are choosing to have children outside of marriage (MukizaGapere \& Ntozi 1995). In 2009, 51.5 per cent of men and 34.3 per cent of women (ages 15 to 49) in Lesotho had never married. Yet the fertility rate remains high, especially among rural populations, at an average of four births per woman (Lesotho Ministry of Health and Social Welfare 2010). During my initial exploratory research, I asked for paternal information as part of standard household data collection. If a girl was unmarried, the common response was that the father was unknown. These de facto fatherless children are disadvantaged in that the disassociation with their paternal kin reduces their potential network of kin-based support. However, a possible benefit is that it allows young women to participate in childbearing, which is still an important rite of passage for many African women (Booth 2004; Pearce 1995), while protecting them and their natal kin's status as primary caregiver if the relationship fails or they die.

Inherent tensions in current caregiving trends exist because caregivers are in short supply. Families engage in contested negotiations about who will care for orphans, as children are 
highly valued by Basotho, but they also often have intensive caregiving needs. These tensions result from the complex ways people regard their social and moral obligations to kin and the extremely limited resources families may be able to devote to another dependent child. These dynamics are further complicated by the expectation that children will be a potential source of labour as they age. The caregivers' anxieties examined here stem at least in part from the potential for loss of labour, although in many cases the child's long-term survival at the time of household migration was not assured. Additionally, while the care of young children costs a great deal of time and energy, the care of older children requires considerable investments in education. These various tensions leading to decisions about care point to a range of competing pressures which caregivers must navigate. In several cases, caregivers were initially reluctant to care for the children but ultimately expressed satisfaction with their living situation because they established reciprocal dependencies as well as emotional bonds with them.

The negotiation of care for 3-year-old Lebo and his siblings was such a case. 'M'e Masello, the maternal grandmother, initially did not want to care for the children, yet she was deemed to be the best person by the paternal family, and therefore the children were left with her. She explained how she came to care for the children:

After the death of [Lebo's] mother, when we were at the funeral ... they said that I should take the child. And I said, how will I take the child yet I'm sick? And the thieves have taken all my animals. And at least there, he will have milk to eat, and I refused to take him ... this child is yours not mine. And after I buried the mother, three days passed ... they came and brought this baby saying their mother said this child is supposed to be here ...Yet I said I don't need him. And they left him. He was very sick. He was very sick. He nearly died ...

'M'e Masello highlights the complexity of fostering AIDS orphans. She felt that she did not have the resources or physical capabilities to care for Lebo and his siblings, yet there was no one else willing to care for them. The children were left with her after lengthy discussions between the two families and their chiefs. However, this does not indicate any lack of love or affection for the children on her part. She was particularly close with Lebo. She often emphasized how happy she was to be living with the children, and how much they helped her. Nevertheless, although she was deemed most capable of caring for Lebo and his siblings, this did not mean that they were ensured adequate care. Although, initially, 'M'e Masello was physically and mentally able to provide for the children, for the last year of her life she was unable to give them the care they needed. This was especially true for Lebo, whose HIV regimen was particularly complex owing to numerous misdiagnoses. As a result of his grandmother's sickness, his adherence to his antiretroviral treatment declined. I learned recently that 'M'e Masello had died. Now the struggle to find a caregiver for the children has begun again.

\section{Conclusion}

A history of dependence on migrant labour, changing marriage practices, and HIV/ AIDS have altered kin-based fostering networks among Basotho families. More children are in need of care, yet there are fewer caregivers to provide it. In rural communities, where 
institutionalized care is unavailable and external support is limited, kin-based care is the only option. In order to cope with these pressures, families are organizing themselves by focusing their resources matrilocally. Yet they are making sense of this model of care within the patrilineal system of child fostering. This is most evident in the ways family members negotiate for the care of children. In particular, primarily elderly female caregivers attempt to demonstrate their right to the children, often focusing on the presence or absence of bridewealth as key to their negotiation strategies. Simultaneously, there is an overriding emphasis on the quality of care that potential caregivers can provide (Ksoll 2007).

The day-to-day role of women in this system has not drastically changed: women still do the majority of the care work. In fact, women are being called upon to care for an increased number of children - including those with greater health problems - yet with diminishing resources. What has changed, however, is the role a woman's natal family plays in supporting her. In a context where marriage is a risk factor for contracting HIV (Smith 2007), but where having children still holds significant social value (Booth 2004), an easily dissolvable marriage may be seen as advantageous by mothers and maternal grandmothers, who can manipulate this flexibility in order to achieve certain caregiving ends. Yet this flexibility is shaped by structural conditions that also create significant challenges for caregivers. Generalized poverty, a significant decline in bridewealth practices, and women's increased access to education, land, and cash income all serve to make marriage more easily dissolvable or even less desirable to begin with. This lessens the power and appeal of patrilineal fosterage patterns. These trends are economically and ideologically ambiguous as maternal kin increasingly have both the burden and the privilege of caring for their daughters' children, while children have narrowed options for receiving support.

According to the 'official kin', the rules of child fostering are rigid and fixed. In practice, however, fostering allows for a wide array of household configurations that are negotiated based on a range of competing ideologies. As Alber notes in her study of child fostering in Benin, the lived experiences of people are 'more flexible and varied than the rules suggest' (2004: 36). Caregivers who are trying to legitimate their right to care for a child emphasize the rigidity of the rules because it allows them strategically to point to the ways in which others are contravening the rules. Comaroff suggests that negotiations around power are 'mediated by the properties of a specific set of rules' (1978: 17).While his study examines the claims to power of Tswana chiefs, I argue that these same processes are replicated on a smaller scale in the negotiations over relatedness that occur in everyday life in Lesotho. Matrilocal caregivers are able to negotiate for the care of children while maintaining the dominant ideology of patrilineal care. In doing so, caregivers have been able to manipulate the tenets of 'official kin' in order to achieve a range of caregiving outcomes, many of which legitimate matrilocal care within the patrilineal system. While these shifting values have markedly changed the caregiving landscape, they have yet to be formally institutionalized precisely because of the focus on patrilineality. In this way, maternal kin are reinforcing the patriarchal structure of the Basotho family in order to privilege their role as caregivers. 


\section{Acknowledgments}

This research was funded by the W.K. Kellogg Family Fellowship in Children and Families and the Population Studies and Training Center (PSTC) at Brown University. The PSTC receives core support from the Eunice Kennedy Shriver National Institute of Child Health and Human Development (5R24HD041020).

I would like to thank MCS staff and caregivers for all their help and support. I am grateful to my writing group at Brown (Adia Benton, Melissa Hackman, and Jennifer Stampe), and to Jessaca Leinaweaver and Mandy Terc for reading earlier versions of this article. Thank you to Justin Dyer for his careful copy-editing.

\section{REFERENCES}

Abebe T, Aase A. Children, AIDS and the Politics of Orphan Care in Ethiopia: The Extended Family Revisited. Social Science \& Medicine. 2007; 64(10):2058-2069. [PubMed: 17379371]

Adato, M.; Kadiyala, S.; Roopnaraine, T.; Biermayr-Jenzano, P.; Norman, A. Children in the Shadow of AIDS: Studies of Vulnerable Children and Orphans in Three Provinces in South Africa. Washington, DC: International Food Policy Research Institute; 2005.

Alber, E. Grandparents as Foster-Parents: Transformations in Foster Relations between Grandparents and Grandchildren in Northern Benin: In Memory of Bona Taowere (C.1910-2000). Vol. 74. Africa: London-International African Institute; 2004. p. 28-46.

Ansell N, Young L. Enabling Households to Support Successful Migration of AIDS Orphans in Southern Africa. AIDS Care. 2004; 16(1):3-10. [PubMed: 14660139]

Ansell N, van Blerk L. Children's Migration as a Household/Family Strategy: Coping with AIDS in Lesotho and Malawi. Journal of Southern African Studies. 2004; 30(3):673-690.

Ashton, EH. The Basuto: A Social Study of Traditional and Modern Lesotho. London, New York: International African Institute by the Oxford U.P.; 1967.

Bledsoe, C. Strategies of Child-Fostering among Mende Grannies in Sierra Leone. In: Lesthaeghe, RJ., editor. Reproduction and Social Organization in Sub-Saharan Africa. Berkeley: University of California Press; 1989. p. 442-474.

Bloch M, Sperber D. Kinship and Evolved Psychological Dispositions: The Mother's Brother Controversy Reconsidered. Current Anthropology. 2002; 43(5):723-748.

Boehm, C. Industrial Labour, Marital Strategy and Changing Livelihood Trajectories among Young Women in Lesotho. In: Christiansen, Catrine; Utas, Mats; Vigh, Henrik, editors. Navigating Youth, Generating Adulthood: Social Becoming in an African Context. Uppsala: Nordiska Afrikainstitutet; 2006. p. 153-182.

Booth, K. Local Women, Global Science: Fighting AIDS in Kenya. Bloomington: Indiana University Press; 2004.

Borneman J. Caring and being Cared for: Displacing Marriage, Kinship, Gender and Sexuality. International Social Science Journal. 1997; 49:573-584.

Bourdieu, P. Marriage Strategies as Strategies of Social Reproduction. In: Forster, Robert; Ranum, Orest, editors. Family and Society. Baltimore: Johns Hopkins University Press; 1976. p. 117-144.

Bourdieu, P. Outline of a Theory of Practice. Cambridge: Cambridge University Press; 1977.

Butler J. Is Kinship always Already Heterosexual. Differences. 2002; 13(1):14.

Carsten, J. Cultures of Relatedness: New Approaches to the Study of Kinship. Cambridge, UK.; New York: Cambridge University Press; 2000. Introduction: Cultures of Relatedness; p. 1-36.

Cole, J. Love in Africa. Chicago: University of Chicago Press; 2009. Love, Money, and Economies of Intimacy in Tamatave, Madagascar; p. 109-134.

Comaroff JL. Rules and Rulers: Political Processes in a Tswana Chiefdom. Man. 1978; 13(1):1-20.

Comaroff JL, Comaroff J. On Personhood: An Anthropological Perspective from Africa. Social Identities. 2001; 7(2):267-283.

Cook J, Boxer A, Burke J, Cohen M, Weber K, Shekarloo P, Lubin H, Mock L. Child Care Arrangements of Children Orphaned by HIV/AIDS: The Importance of Grandparents as Kinship Caregivers. Journal of HIV/AIDS \& Social Services. 2003; 2(2):5-20. 
Cooper E. Sitting and Standing: How Families are Fixing Trust in Uncertain Times. Africa: The Journal of the International African Institute. 2012; 82(3):437-456.

Coplan DB. Fictions that Save: Migrants' Performance and Basotho National Culture. Cultural Anthropology. 1991; 6(2):164-192.

Coplan DB. A River Runs through it: The Meaning of the Lesotho-Free State Border. African Affairs. 2001; 100(398):81-116.

Courtney, ME.; Iwaniec, D. Residential Care of Children: Comparative Perspectives. Oxford; New York: Oxford University Press; 2009.

Crush, J. Migration Policy Series, No 53. Capte Town: 2010. Migration, Remittances and 'Development' in Lesotho. SAMP (Southern Africa Migration Programme).

Department of Social Welfare. [accessed February 26, 2013] National Policy on Orphans and Vulnerable Children, Lesotho. http://www.gov.ls/health/.

Dodoo FN. Marriage Type and Reproductive Decisions: A Comparative Study in Sub-Saharan Africa. Journal of Marriage and the Family. 1998; 60(1):232-242.

Durham, D. Did You Bathe this Morning?: Baths and Morality in Botswana. In: Masquelier, Adeline Marie, editor. Dirt, Undress, and Difference: Critical Perspectives on the Body's Surface. Indiana University Press; 2005. p. 190-212.

Edgar, R.; Levine, ML. Lesotho. In: Middleton, J.; Miller, JC., editors. New Encyclopedia of Africa. 2nd ed.. Vol. 3. Farmington Hills: The Gale Group; 2008. p. 607-608.

Epprecht M. Domesticity and Piety in Colonial Lesotho: The Private Politics of Basotho Women's Pious Associations. Journal of Southern African Studies. 1993; 19(2):202.

Ferguson J. The Bovine Mystique: Power, Property and Livestock in Rural Lesotho. Man. 1985; 20(4): 647-674.

Franklin, S.; McKinnon, S. Introduction: Relative Values: Reconfiguring Kinship Studies. In: Franklin, Sarah; McKinnon, Susan, editors. Relative Values: Reconfiguring Kinship Studies. Durham [N.C.]: Duke University Press; 2001. p. 1-26.

Gay JS. Basotho Women Migrants: A Case Study. The IDS Bulletin. 1980; 11(4):19-28.

Goldberg RE, Short SE. "The Luggage that Isn't Theirs is Too Heavy": Understandings of Orphan Disadvantage in Lesotho. Population Research and Policy Review. 2012; 31(1):67. [PubMed: 22865946]

Goody, EN. Parenthood and Social Reproduction: Fostering and Occupational Roles in West Africa. Cambridge; New York: Cambridge University Press; 1982.

Goody, E. Parental Strategies: Calculation Or Sentiment?: Fostering Practices among West Africans. In: Medick, Hans; Sabean, David Warren, editors. Interest and Emotion: Essays on the Study of Family and Kinship. Cambridge; New York: Cambridge University Press; 1984. p. 266-277.Editions de la Maison des Sciences de l'Homme.

Gordon E. An Analysis of the Impact of Labour Migration on the Lives of Women in Lesotho. The Journal of Development Studies. 1981; 17(3):59-76.

Hosegood V, McGrath N, Moultrie TA. Dispensing with Marriage: Marital Trends in Rural KwaZuluNatal, South Africa 2000-2006. Demographic Research. 2009; 20(13):279-312. [PubMed: 25729322]

Howard BH, Phillips CV, Matinhure N, Goodman KJ, McCurdy SA, Johnson CA. Barriers and Incentives to Orphan Care in a Time of AIDS and Economic Crisis: A Cross-Sectional Survey of Caregivers in Rural Zimbabwe. BMC Public Health. 2006; 6(1):27. [PubMed: 16469104]

Juma, L. Putting Old Wine in New Skins: The Customary Code of Lerotholi and Justice Administration in Lesotho. In: Fenrich, Jeanmarie; Galizzi, Paolo; Higgins, Tracy E., editors. The Future of African Customary Law. Cambridge: Cambridge University Press; 2011. p. 139-152.

Kidman R, Petrow SE, Heymann SJ. Africa's Orphan Crisis: Two Community-Based Models of Care. AIDS Care. 2007; 19(3):326-329. [PubMed: 17453565]

Kimble, J. Labour Migration in Basutoland, C. 1870-1885. In: Marks, Shula; Rathbone, Richard, editors. Industrialisation and Social Change in South Africa: African Class Formation, Culture, and Consciousness, 1870-1930. London: Longman; 1982. p. 119-141. 
Klaits, F. Death in a Church Life: Moral Passion during Botswana's Time of AIDS. Berkeley, CA: University of California Press; 2010.

Ksoll C. Selecting Good Caretakers: The Impact of Family Networks in Tanzania on Orphans' Education. 2010

Kuo C, Operario D. Caring for AIDS-Orphaned Children: A Systematic Review of Studies on Caregivers. Vulnerable Children and Youth Studies. 2009; 4(1):1-12.

Larsson, A. Housing Conflicts and Women's Strategies in Lesotho. In: Schlyter, Ann, editor. A Place to Live: Gender Research on Housing in Africa. Uppsala: Nordic Africa Institute; 1996. p. 64-76.

Leinaweaver J. On Moving Children: The Social Implications of Andean Child Circulation. American Ethnologist. 2007; 34(1):163-180.

Lesotho Ministry of Health and Social Welfare. [Accessed January 24, 2011] Lesotho Demographic and Health Survey. 2009. http://pdf.usaid.gov/pdf_docs/PNADU407.pdf.

Levi-Strauss, C. The Elementary Structures of Kinship. Boston: Beacon Press; 1969. The Elementary Structures of Kinship.

Livingston J. Disgust, Bodily Aesthetics, and the Ethic of being Human in Botswana. Africa. 2008; $78(2): 288$.

Madhavan S. Fosterage Patterns in the Age of AIDS: Continuity and Change. Social Science \& Medicine. 2004; 58(7):1443-1454. [PubMed: 14759688]

Mapetla; Matseliso, M. SADC Gender Protocol Barometer Baseline Study: Lesotho. Roma, Lesotho: National University of Lesotho; 2009.

Marks S. An Epidemic Waiting to Happen? the Spread of HIV/AIDS in South Africa in Social and Historical Perspective. African Studies. 2002; 61(1):13.

Meekers D, Calves AE. Main Girlfriends, Girlfriends, Marriage, and Money: The Social Context of HIV Risk Behaviour in Sub-Saharan Africa. Health Transition Review. 1997; 7(Supplement):361375. [PubMed: 10169655]

Meekers D. The Process of Marriage in African Societies: A Multiple Indicator Approach. Population and Development Review. 1992; 18(1):61.

Mokomane Z. Social Protection as a Mechanism for Family Protection in Sub-Saharan Africa. International Journal of Social Welfare. 2013; 22(3):248-259.

Mueller M. Women and Men, Power and Powerlessness in Lesotho. Signs. 1977; 3(1):154-166.

Mukiza-Gapere J, Ntozi JPM. Impact of AIDS on Marriage Patterns, Customs and Practices in Uganda. Health Transition Review Sup. 1995; 5:201-208.

Murray C. Marital Strategy in Lesotho: The Redistribution of Migrant Earnings. African Studies. 1976; 35(2):99-122.

Murray, C. African Studies Series. Cambridge; New York: Cambridge University Press; 1981. Families Divided: The Impact of Migrant Labour in Lesotho; p. 29

Murray C. High Bridewealth, Migrant Labour and the Position of Women in Lesotho. Journal of African Law. 1977; 21:79-96. (1, Honour of Isaac Schapera). [PubMed: 12339092]

Murray C. Migrant Labour and Changing Family Structure in the Rural Periphery of Southern Africa. Journal of Southern African Studies. 1980; 6(2):139-156.

Nyambedha EO, Wandibba S, Aagaard-Hansen J. Retirement Lost -the New Role of the Elderly as Caretakers for Orphans in Western Kenya. Journal of Cross-Cultural Gerontology. 2003; 18(1): 33-52. [PubMed: 14617957]

Nyesigomwe L. Strengthening the Capacity of Grandparents in Providing Care to Young Children Affected by HIV/AIDS. Journal of Intergenerational Relationships. 2005; 4(1):55-63.

Oleke C, Blystad A, Rekdal OB. "When the Obvious Brother is Not there": Political and Cultural Contexts of the Orphan Challenge in Northern Uganda. Social Science \& Medicine. 2005; 61(12): 2628-2638. [PubMed: 15979773]

Page, H. Childrearing Versus Childbearing: Coresidence of Mother and Child in Sub-Saharan Africa. In: Lesthaeghe, RJ., editor. Reproduction and Social Organization in Sub-Saharan Africa. Berkeley: University of California Press; 1989. p. 401-441. 
Pearce, T. Women's Reproductive Practices and Biomedicine: Cultural Conflicts and Transformations in Nigeria. In: Ginsburg, FD.; Rapp, Rayna, editors. Conceiving the New World Order: The Global Politics of Reproduction. Berkeley, CA: University of California Press; 1995. p. 195-208.

Poulter S. Marriage, Divorce and Legitimacy in Lesotho. J Afr Law. 1977; 21(1):66-78.

Prazak M. Studying Life Strategies of AIDS Orphans in Rural Kenya. Africa Today. 2012; 58(4):4464.

Radcliffe-Brown, AR.; Forde, CD. African Systems of Kinship and Marriage. London, New York: Published for the International African Institute by the Oxford University Press; 1950.

Renne, EP. History in the Making: An Anthropological Approach to the Demographic Analysis of Child Fostering in Southwestern Nigeria. International Population Conference, IUSSP; Montreal. 1993. p. 327-342.

Robson E, Ansell N, Huber US, Gould WTS, van Blerk L. Young Caregivers in the Context of the HIV/AIDS Pandemic in Sub-Saharan Africa. Population, Space and Place. 2006; 12(2):93-111.

Romero-Daza, N.; Himmelgreen, D. More than Money for Your Labor: Migration and the Political Economy of AIDS in Lesotho. In: Singer, Merrill, editor. The Political Economy of AIDS. Amityville, N.Y.: Baywood Pub; 1998. p. 185-204.

Schrauwers A. Negotiating Parentage: The Political Economy of "Kinship" in Central Sulawesi, Indonesia. American Ethnologist. 1999; 26(2):310-323.

Smith DJ. Modern Marriage, Men's Extramarital Sex, and HIV Risk in Southeastern Nigeria. American Journal of Public Health. 2007; 97(6):997-1005. [PubMed: 17463366]

Smith DJ. Premarital Sex, Procreation, and HIV Risk in Nigeria. Studies in Family Planning. 2004; 35(4):223-235. [PubMed: 15628781]

Spiegel AD. Changing Patterns of Migrant Labour and Rural Differentiation in Lesotho. Social Dynamics. 1981; 6(2):1-13.

Townsend NW. Men, Migration, and Households in Botswana: An Exploration of Connections Over Time and Space. Journal of Southern African Studies. 1997; 23(3):405-420.

Townsend L, Dawes A. Willingness to Care for Children Orphaned by HIV/AIDS: A Study of Foster and Adoptive Parents. African Journal of AIDS Research. 2004; 3(1):69-80. 2004.

Turkon D. Modernity, Tradition and Nuances of Class in Lesotho. City \& Society. 2009; 21(1):82107.

Turkon D. Modernity, Tradition and the Demystification of Cattle in Lesotho. African Studies. 2003; 62(2):147-169.

Turkon D, Himmelgreen D, Romero-Daza N, Noble C. Anthropological Perspectives on the Challenges to Monitoring and Evaluating HIV and AIDS Programming in Lesotho. African Journal of AIDS Research. 2009; 8(4):473-480.

UNAIDS. Lesotho Global AIDS Response Country Progress Report. 2012 http://www.unaids.org/en/ dataanalysis/knowyourresponse/countryprogressreports/2012countries/ce_LS_Narrative_Report $\% 581 \% 5$ D.pdf.

UNICEF. Children and AIDS: Fifth Stocktaking Report. 2010 http://www.unicef.org/publications/ files/Children_and_AIDS-Fifth_Stocktaking_Report_2010_EN.pdf.

Urassa M, Boerma JT, Isingo R, Ngalula J, Ng'weshemi J, Mwaluko G, Zaba B. The Impact of HIV/ AIDS on Mortality and Household Mobility in Rural Tanzania. Aids. 2001; 15(15):2017-2023. [PubMed: 11600831]

Wardlow, H. Wayward Women: Sexuality and Agency in a New Guinea Society. Berkeley: University of California Press; 2006.

Zagheni E. The Impact of the HIV/AIDS Epidemic on Kinship Resources for Orphans in Zimbabwe. Population and Development Review. 2011; 37(4):761-783. [PubMed: 22319773] 